\title{
MENINGKATKAN AKTIVITAS PESERTA DIDIK DALAM PEMBELAJARAN PPKN MELALUI WHATSAPP
}

\section{TO INCREASE LEANERS ENGAGEMENT ON STUDY PPKN THROUGH WHATSAPP}

\author{
WIJIANA \\ SMP Negeri 87 Jakarta
}

\begin{abstract}
Received: March 09, 2021

Most students are not enthusiastic about participating in online learning. Therefore we need a Revised: September 30, 2021 way to activate students in learning through WhatsApp Groups. This research aims to determine Accepted: November 26, 2021 the increase in students activity through WhatsApp in PPKN learning on basic competence analysis the forming process of Pancasila as fundament philosophy. The subject on this research is students of 87 Junior High School for the seventh grades. This research with 2 cycles. Each cycles consists of four stages, namely planning, implementing, acting, observing and reflecting. Data collection techniques carried out by monitoring during studying and taking test on the learners. In this research there are two research instruments, namely observation sheets and test. From the results, it is found out the learning outcome of learners knowleadge increased from $68 \%$ to $77 \%$ in cycle and cyclus II became 89\%. It can be concluded that learning PPKN through WhatsApp can improve students activities
\end{abstract}

\begin{abstract}
Abstrak.
Sebagian besar peserta didik dalam pembelajaran daring tidak antusias mengikuti pembelajaran secara sungguh-sungguh. Oleh sebab itu diperlukan cara untuk mengaktifkan peserta didik dalam pembelajaran melalui WhatsApp Group. Penelitian ini bertujuan untuk mengetahui adanya peningkatan aktivitas peserta didik melalui media pembelajaran WhatsApp dalam pembelajaran PPKn khususnya pada kompetensi dasar menelaah proses penyusunan Pancasila sebagai dasar negara. Subjek dalam penelitian ini adalah peserta didik kelas VII SMPN 87 Jakarta. Penelitian ini menggunakan penelitian tindakan kelas sebanyak 2 siklus. Setiap siklus terdiri dari empat tahapan, yaitu perencanaan, tindakan, pengamatan dan refleksi. Tahap pelaksanaan pada setiap siklus dilaksanakan dalam dua kali pertemuan. Teknik pengambilan data dilakukan dengan pemantauan dan melakukan tes terhadap peserta didik. Di dalam penelitian ini menggunakan beberapa instrumen penelitian berupa lembar observasi dan test. Dari hasil penelitian didapatkan bahwa hasil aktivitas peserta didik mengalami kenaikan dari prasiklus 68\%, siklus I meningkat menjadi $77 \%$, dan siklus II meningkat menjadi 89\%, sehingga berpengaruh terhadap hasil belajar yang sebelum diadakan penelitian hasil belajar yang dicapai prasiklus adalah rata ratanya 65,8 dengan pencapaian ketuntasannya adalah 53\%, kemudian pencapaian setelah siklus I yaitu rata ratanya $73 \%$ sedang ketuntasannya mencapai $69 \%$ dan siklus II ada kenaikkan yang signifikan menjadi $80,8 \%$ dan pencapaian ketuntasannya adalah 89\%. Berdasarkan penilaian tersebut dapat disimpulkan bahwa pembelajaran PPKn melalui WhastApp dapat meningkatkan aktivitas peserta didik
\end{abstract}

Keywords: WhatsApp, online learning, media for learning

Kata kunci: WhatsApp, pembelajaran daring, media pembelajaran

$\left(^{\star}\right)$ Corresponding Author: wijiana@gmail.com

How to Cite: Wijiana, (2021). Meningkatkan Aktivitas Peserta Didik Dalam Pembelajaran Ppkn Melalui Whatsapp. Jurnal Lingkar Mutu Pendidikan, 18 (2), 243-250. https://doi.org/10.54124/jlmp.v18i1.37

\section{PENDAHULUAN}

Penyebaran virus corona yang sangat cepat dan mematikan bagi golongan-golongan tertentu. Membuat banyak negara di dunia ini mengubah kebijakan-kebijakan yang terkait dengan berkumpulnya masyarakat, tak terkecuali dalam dunia pendidikan. Hal ini dapat dilihat pada Surat Edaran Mendikbud RI Nomor 3662/MPK.A/HK/2020 mengenai pembelajaran yang dilaksanakan melalui sistem online atau virtual tanpa tatap muka. Sehingga terjadi tranformasi dalam dunia pendidikan dari pendidikan di sekolah menjadi pendidikan di rumah. Hal ini membuat hubungan 
antara guru dan orang tua mempunyai peran yang sangat penting dalam mengaktifkan pembelajaran di rumah atau yang disebut dengan nama pembelajaran secara daring.

Pembelajaran secara daring merupakan sistem pembelajaran yang kompleks. Pembelajaran daring akan berhasil jika memperhatikan beberapa faktor antara lain bagaimana materi pelajaran sampai pada peserta didik, bagaimana materi membuat mudah diterima bagi peserta didik, pembelajaran daring yang mendukung gaya belajar peserta didik, pembelajaran yang dapat menambah pengetahuan dan kompetensi peserta didik, dan pembelajaran yang mudah diterima informasinya bagi peserta didik. Sehingga pembelajaran tersebut akan dapat meningkatkan aktivitas peserta didik.

Aktivitas dalam pembelajaran sudah dapat dipastikan akibat adanya respon dan stimulus yang telah dirancang oleh seorang guru agar pembelajaran berhasil dilaksanakan. Menurut Skinner belajar adalah mengubah apa yang kita lakukan (Gredler 2011, 120). Thorndike telah mengidentifikasikan tiga komponen utama dalam transformasi tingkah laku yaitu kesempatan dimana tingkah laku terjadi, tingkah laku itu sendiri, dan konsekuensi dari perilaku tersebut (Gredler 2011, 120). Sehingga alangkah tepat sekali jika dalam pembelajaran daring diberikan stimulus untuk menghasilkan konsekuensi yang berbeda dan konsekuensi tertentu menimbulkan mengulang respon. Sehingga pembelajaran dapat berhasil karena adanya aktivitas tertentu yang dapat menghasilkan penguatan. Dalam hal ini istilah "konsekuensi" menurut Thorndike diganti oleh Skinner menjadi penguatan (Gredler 2011, 120). Bagaimana stimulus menjadi penguat? Menurut Skinner, prosesnya dimulai dengan penguatan primer, pengkondisian, dan generalisasi (Gredler 2011, 126). Salah satu indikator keberhasilan pembelajaran adalah jika transfer kontrol stimulus berhasil dengan baik. Oleh sebab itu agar transfer kontrol stimulus berhasil dengan baik maka pertama-tama dalam perencanaan pembelajaran untuk membentuk tingkah laku adalah mengklasifikasikan dengan jelas perilaku yang akan dipelajari (Gredler 2011, 122). Langkah selanjutnya mengidentifikasikan keterampilan awal peserta didik. Hal ini jelas bahwa perilaku peserta didik adalah hal utama yang harus diperhatikan dalam mencapai tujuan belajar. Aktivitas atau perilaku dapat diubah. Ada beberapa macam kegiatan atau aktivitas murid antara lain: 1) visual activities seperti membaca, mengamati gambar, demonstrasi, dan eksperimen; 2) oral activities seperti membuat pernyataan, merumuskan, bertanya, memberi saran dan pendapat, serta melakukan wawancara, diskusi, dan interupsi; 3) listening activities seperti mendengarkan uraian, percakapan, diskusi, musik, dan pidato; 4) writing activities seperti membuat cerita, karangan, laporan tes, angket, dan menyalin; 5) drawing activities seperti menggambar, membuat grafik, peta, diagram, dan pola; 6) motor activities seperti melakukan eksperimen, membuat konstruksi, model, mereparasi, bermain, berkebun, dan memelihara binatang; 7) mental activities, seperti mengingat, problem solving, menganalisis, melihat hubungan, dan membuat keputusan; 8) emotional activities seperti menaruh minat, merasakan jenuh, bahagia, berani, tenang, dan gugup.

Menurut Ali Sadikin pembelajaran secara daring adalah pembelajaran yang menggunakan akses internet dengan aksesibilitas, koneksitas, fleksibilitas dan kemampuan untuk menimbulkan berbagai macam interaksi pembelajaran (Sadikin 2020, 126). Agar pembelajaran secara daring berjalan dengan baik maka dibutuhkan berbagai perangkat yang mendukung terlaksananya pembelajaran daring tersebut.

Pada kenyataannya sebagian besar peserta didik dalam pembelajaran daring tidak antusias mengikuti pembelajaran secara sungguh-sungguh. Hal ini memengaruhi secara signifikan terhadap hasil belajar. Mereka hanya sekedar memenuhi kewajiban dengan cara mengerjakan tugas saja itu pun diujung waktu. Hal ini disebabkan peserta didik merasa tidak terkontrol oleh pengajar. Oleh sebab itu diperlukan bagaimana caranya mengaktifkan peserta didik dalam pembelajaran melalui WAG (WhatsApp Group). Karena media yang sangat mudah dan dekat dengan mereka adalah WhatsApp. Disamping WhatsApp tidak membutuhkan kuota yang besar. Dengan demikian terjangkau bagi semua peserta didik dari semua kalangan. Sehingga pengajar akan mudah mengirimkan pengetahuan dimana pengetahuan tersebut harus sampai pada peserta didik, mengorganisasi peserta didik, memastikan peserta didik ikut secara aktif dalam pembelajaran atau tidak, dan dapat meminta umpan balik dari peserta didik ketika pengajar menyampaikan materi.

WhatsApp merupakan aplikasi pesan instan untuk smartphone. Jika dilihat dari fungsinya, WhatsApp memiliki fungsi yang hampir sama dengan aplikasi SMS namun menggunakan data internet dan tidak menggunakan pulsa. Mengirim pesan teks, mengirim foto dari galeri ataupun kamera, dan 
mengirim video merupakan fitur-fitur yang ada dalam WhatsApp. Sedemikian lengkapnya fitur-fitur dari WhatsApp, sehingga WhatsApp dijadikan sarana atau media untuk pembelajaran menggantikan pembelajaran di kelas.

Berdasarkan kondisi tersebut diatas maka digunakan suatu metode pembelajaran yang dapat meningkatkan kegiatan peserta didik dan memunculkan sikap berani mengeluarkan pendapat sehingga meningkatkan hasil belajar. Penggunaan metode tersebut kemudian dibuat Penelitian Tindakan Kelas dengan judul "Meningkatkan Aktivitas Peserta Didik dalam Pembelajaran PPKn melalui WhatsApp"

Berdasarkan latar belakang tersebut, maka dapat dirumuskan masalah sebagai berikut: apakah WhatssApp dapat meningkatkan aktivitas peserta didik dalam pembelajaran PPKn khususnya pada kompetensi dasar menelaah penyusunan dasar negara? Penelitian ini bertujuan untuk mengetahui apakah ada peningkatan aktivitas peserta didik melalui media pembelajaran WhatsApp dalam pembelajaran PPKn khususnya pada kompetensi dasar menelaah proses penyusunan Pancasila sebagai dasar negara. Melalui penelitian ini diharapkan akan menghasilkan manfaat antara lain melatih peserta didik untuk bersikap kerjasama, peserta didik terbiasa mengemukakan pendapat, peserta didik lebih menguasai pemahaman konsep kompetensi dasar menelaah penyusunan dasar negara, wawasan peserta didik dapat berkembang dan terarah, melibatkan secara aktif dalam pembelajaran, guru lebih variatif dan inovatif memilih metode, serta media dan strategi pembelajaran yang relevan"

\section{METODE PENELITIAN}

Penelitian tindakan kelas ini dilakukan pada bulan September dan Oktober 2020. Lokasi penelitian di SMP Negeri 87 dengan alamat Jalan Ciputat Raya Pondok Pinang. Subjek penelitian ini peserta didik kelas VII-1 yang berjumlah 39 orang. Jenis penelitian ini merupakan Penelitian Tindakan Kelas. Adapun jenis tindakan yang diteliti adalah aktivitas peserta didik dalam proses pembelajaran daring, sikap peran serta peserta didik dapat dimunculkan selama proses pembelajaran, dan hasil belajar peserta didik melalui tes.

Untuk mendapatkan data yang diperlukan dalam penelitian maka menggunakan teknik pengumpulan data berupa metode observasi dan evaluasi berupa tes. Observasi dilaksanakan selama proses belajar mengajar dengan menggunakan untuk mengetahui kegiatan peserta didik selama proses pembelajaran daring. Observasi dilaksanakan dengan menggunakan lembar observasi aktivitas peserta didik melalui respon-respon peserta didik selama pembelajaran daring berjalan.

Metode evaluasi (tes) digunakan untuk mengetahui kenaikan hasil belajar peserta didik secara perorangan maupun klasikal pada ketuntasan belajarnya.

Teknik analisa data dilakukan dengan cara data yang telah dikumpulkan pada tiap siklus dianalisa dan dibuat kesimpulan dari tiap siklusnya. Bila dalam satu siklus masih ada kekurangan maka kekurangan tersebut diperbaiki dan dilanjutkan pada siklus berikutnya dengan menambah atau memperbaiki pembelajaran berikutnya dan seterusnya sampai diperoleh hasil belajar yang memuaskan.

Langkah-langkah penelitian ini sebagai berikut: pada tahap planning meliputi menentukan Kompetensi Dasar dan Indikator Pencapaian Kompetensi menelaah penyusunan dasar negara, waktu pelaksanaan, rencana pembelajaran dan pembuatan indikator keberhasilan dalam penelitian. Menyusun lembar kerja peserta didik, menyiapkan lembar observasi untuk menuliskan aktivitas peserta didik. Tugas diberikan pada peserta didik pada setiap kegiatan pembelajaran.

Pada tahap tindakan meliputi proses pembelajaran melalui keaktifan dan peran serta dalam pembelajaran daring. Pada tahap ini stimulus diberikan oleh guru. Jika stimulus berhasil di evaluasi melalui tes, maka tindakan tersebut dihentikan artinya tidak diperlukan siklus berikutnya.

Pada tahap observasi dilakukan bersamaan dengan proses pembelajar, meliputi kegiatan peserta didik dan hasil belajar peserta didik. Untuk lebih menghasilkan data yang objektif, observasi dilakukan dengan langkah-langkah sebagai berikut: guru meneliti aktivitas peserta didik selama pembelajaran, guru meneliti secara seksama pemahaman peserta didik terhadap materi pelajaran, dan peserta didik mengumpulkan hasil tes.

Pada tahap refleksi meliputi hasil belajar peserta didik dan sekaligus membuat rencana perbaikan pada siklus selanjutnya, mengadakan pencatatan hasil observasi, mengadakan evaluasi hasil 
observasi, mengadakan analisa hasil observasi dan pembelajaran, serta mengadakan penyempurnaan dan perbaikan sebagai siklus berikutnya.

Indikator keberhasilan adalah ketika peserta didik mampu melampaui KKM yang disebut dengan nama ketuntasan, berperan aktif dalam pembelajaran melalui aktivitas verbal, aktivitas mental, dan aktivitas emosi.

\section{HASIL DAN PEMBAHASAN}

Sebelum melakukan penelitian, telah diamati bahwa pembelajaran daring melalui WAG mengalami banyak masalah antara lain anak anak kurang aktif dan hasil tugas yang diberikan kurang memuaskan. Kemudian mendokumentasikan yang dianggap sebagai pra siklus. Pencapaian ketuntasan hanya sampai pada 53\%, sehingga harus dilakukan remedial. Hal inilah yang menjadi dasar untuk menerapkan beberapa stimulus dalam pembelajaran untuk mempengaruhi perilaku peserta didik. Dengan berbagai pertimbangan maka ditetapkan bahwa media pembelajaran yang dipakai dalam pembelajaran daring adalah melalui WAG, untuk menemukan cara supaya pembelajaran dapat berjalan secara efektif dan peserta didik bisa berinteraksi dengan baik. Kemudian dilakukan beberapa transfer of control stimulus atau mengubah perilaku peserta didik pada saat pembelajaran berlangsung melalui WAG tersebut. Cara mengubah perilaku (transfer of control stimulus) peserta didik melalui dua siklus penelitian.

Tabel 1. Perbedaan perlakuan dalam setiap siklus

\begin{tabular}{lll}
\hline \multicolumn{1}{c}{ Pra Siklus } & \multicolumn{1}{c}{ Siklus I } & \multicolumn{1}{c}{ Siklus II } \\
\hline $\begin{array}{l}\text { Peserta didik mengisi kehadiran } \\
\text { melalui tulisan di WAG }\end{array}$ & $\begin{array}{l}\text { Peserta didik mengisi kehadiran melalui } \\
\text { vengirim PowerPoint melalui }\end{array}$ & $\begin{array}{l}\text { Peserta didik mengisi kehadiran melalui } \\
\text { voice mail di WAG }\end{array}$ \\
WAG & $\begin{array}{l}\text { Guru menjelaskan PowerPoint melalui } \\
\text { voice mail di WAG }\end{array}$ & $\begin{array}{l}\text { Guru menjelaskan PowerPoint melalui } \\
\text { voice mail di WAG }\end{array}$ \\
& $\begin{array}{l}\text { Guru melakukan tanya jawab voice mail } \\
\text { di WAG }\end{array}$ & $\begin{array}{l}\text { Guru melakukan tanya jawab voice mail } \\
\text { di WAG }\end{array}$ \\
& Evaluasi pembelajaran per IPK (Indikator & IPK di-breakdown lebih sederhana lagi \\
& Pencapaian Kompetensi) & \\
& & Peserta didik diberi motivasi berupa nilai \\
& Peserta didik melakukan refleksi melalui \\
& voice mail \\
\hline
\end{tabular}

Alur atau tahapan PTK ini adalah perencanaan, pelaksanaan, pengamatan, dan refleksi dibuat dalam tiga siklus yaitu: 1) kompetensi yang dipelajari pada pra siklus adalah meliputi indikator pencapaian kompetensi mendeskripsikan proses pembentukan BPUPKI; 2) perencanaan pra siklus, langkah-langkah yang dilakukan pada perencanaan ini adalah membuat analisis materi pelajaran dan menentukan transfer control stimulus yang akan ubah; 3) menyusun rencana pembelajaran, menyusun bahan tes evaluasi, menentukan subjek penelitian, menyusun jadwal pelaksanaan, menyusun instrumen penelitian berupa lembar observasi; 4) pelaksanaan tindakan pada pra siklus I dilakukan pada minggu kedua bulan Agustus 2020. Guru dalam menyampaikan materi pelajaran melakukan langkah-langkah sebagai berikut: guru menyampaikan Kompetensi Dasar dan Indikator Pencapaian Kompetensi, guru merumuskan tujuan pembelajaran, peserta didik memberi absen tulisan nama di WAG, peserta didik membaca, menulis materi yang terdapat di PowerPoint, dan mengerjakan evaluasi yang tertulis di SIMAK; 5) observasi, untuk lebih menghasilkan data yang objektif observasi dilakukan dengan langkah-langkah sebagai berikut: guru meneliti aktivitas peserta didik selama pembelajaran, guru meneliti secara seksama pemahaman peserta didik terhadap materi pelajaran, peserta didik mengumpulkan hasil belajar; 6) refleksi, yang dilakukan pada pra siklus adalah mengadakan pencatatan hasil observasi sehingga dapat diperoleh aktifitas verbal yang meliputi kemampuan berpendapat hanya mencapai 58\%, kemampuan bertanya mencapai 52\%, kemampuan memberi saran 51\%, sedangkan aktivitas mental kemampuan menanggapi 53\%, menjawab pertanyaan 51\%, mengambil keputusan 50\%, dan mengingat mencapai 49\%. Sedangkan pencapaian kemampuan emosi meliputi 
kehadiran $67 \%$, berani $58 \%$, bersemangat $46 \%$, dan tes hasil belajar memperoleh rata-rata 65,8 dengan ketuntasan yang mencapai KKM sebanyak 53\% dari jumlah peserta didik sebanyak 39. Dari hasil tes tersebut maka diberi tindakan remedial dan pemberian stimulus melalui WAG kepada peserta didik, untuk melakukan langkah-langkah tertentu melalui WAG dalam pembelajaran.

Materi pada siklus I adalah mendeskripsikan proses penyusunan Piagam Jakarta. Dalam upaya memperbaiki kelemahan yang didapat pada siklus I maka perencanaan pelaksanaan pada siklus I diantaranya, menyusun dan menyempurnakan rencana pembelajaran perbaikan, peserta didik diminta untuk mengabsen suara (menyebutkan nama, kelas, dan nomor absen). Kemudian guru menjelaskan melalui voice mail, guru mengadakan tanya jawab melalui voice mail WAG, peserta didik merespon pertanyaan guru, dan mengerjakan soal pada SIMAK secara langsung.

Pelaksanaan tindakan pada Siklus I dilaksanakan pada minggu pertama bulan September 2020, guru memberikan materi pelajaran dengan langkah-langkah sebagai berikut: guru menyampaikan Kompetensi Dasar dan IPK, guru menyampaikan tujuan pembelajaran, absen suara, guru mengirim file materi melalui $W A G$, peserta didik membaca dan merangkum dari file materi, guru menjelaskan melalui voice mail, peserta didik dimotivasi untuk merespon dan menjawab pertanyaan guru, dan peserta didik melakukan evalusi di SIMAK.

Hasil observasi pada siklus I ada peningkatan yang signifikan yaitu aktivitas verbal yang meliputi keberanian untuk mengeluarkan pendapat mencapai $64 \%$, untuk motivasi bertanya hanya mencapai $53 \%$, memberikan saran 50\%, begitu juga dalam aktivitas mental meliputi kemampuan menanggapi hanya 54\% hanya mengalami kenaikkan angka 1 saja, kemampuan mengambil keputusan 69\%, naik dari 50\% menjadi 69\%. Kenaikkan sebesar 19\%, sedangkan kemampuan mengingat mencapai 60\%, terjadi kenaikkan angka sebesar $29 \%$ saja. Aktivitas emosi dengan kehadiran $74 \%$, terjadi kenaikkan $7 \%$, serta motivasi mereka naik yang awalnya hanya $46 \%$ menjadi $59 \%$. Sedangkan pencapaian hasil belajar rata-rata mengalami kenaikkan yang awalnya hanya 65,8 berubah menjadi 73 , dan peserta didik yang tuntas dalam pembelajaran sebanyak 21 orang sehingga yang perlu mendapat remedial sebanyak 18 orang.

Pada saat refleksi di siklus I guru mengevaluasi materi yang kurang dikuasai anak yang nilainya masih dibawah KKM sebanyak 18 peserta didik, sehingga perlu penyempurnaan dan perbaikan, pembuatan materi soal, dan memberi stimulus yang baru agar peserta didik yang nilainya masih di bawah KKM dapat memperoleh nilai melampaui KKM.

Perencanaan pada siklus II memperbaiki hasil yang diperoleh pada siklus I, maka perencanaan pelaksanaan pada siklus II diantaranya: menyusun dan menyempurnakan rencana pembelajaran perbaikan, peserta didik diminta untuk mengabsen suara (sebut nama, kelas, dan nomor absen), guru menjelaskan melalui voice mail, guru mengadakan tanya jawab melalui voice mail WAG, peserta didik merespon pertanyaan guru, KD di-breakdown menjadi beberapa IPK yang lebih sederhana dan penyampaian per pertemuan satu IPK yang sederhana, dan mengerjakan SIMAK langsung.

Pelaksanaan tindakan pada siklus II dilakukan pada minggu ke 4 bulan September 2020, materi pelajaran disampaikan dengan langkah-langkah sebagai berikut: guru menyampaikan Kompetensi Dasar dan IPK, guru menyampaikan tujuan pembelajaran, absen suara, guru mengirim PowerPoint melalui WAG, peserta didik membaca dan merangkum PowerPoint, guru menjelaskan melalui voice mail, dan peserta didik diberi motivasi berupa hadiah nilai jika menjawab pertanyaan dan merespon dalam WAG saat KBM. Untuk evaluasi hasil pembelajarannya dilakukan per IPK.

Pada saat observasi siklus II, guru tetap mengamati keaktifan peserta didik, guru mengamati aktivitas peserta didik selama diskusi, guru meneliti secara seksama pemecahannya terhadap materi pelajaran, bersama mitra kerja (pembimbing) mengadakan pengamatan, pemantauan sebagai evaluasi dan refleksi. Hasil yang diperoleh dengan memberi stimulus berupa transfer control stimulus yaitu hadiah nilai, maka peserta didik berlomba-lomba untuk menjawab dan merespon selama pembelajaran berlangsung, baik melalui voice maupun menulis di WAG sebagai keterlibatan peserta didik dalam pembelajaran. Hasil yang diperoleh ada peningkatan secara signifikan pada siklus II ini yaitu aktivitas verbal yang meliputi kemampuan bertanya sebesar $71 \%$, dalam hal ini naik dari siklus I 64\% menjadi $71 \%$. Hal ini menunjukkan peserta didik sangat antusias untuk menyampaikan pendapatnya. Bila dibandingkan dengan pembelajaran secara langsung atau luring, peserta didik lebih banyak pasif karena segan atau malu bertanya pada guru. Namun ketika pembelajaran melalui WAG justru peserta 
didik terpacu untuk memberi respon, pertama merespon berarti mendapat nilai, merespon berarti hadir, begitu juga kemampuan bertanya mengalami kenaikkan menjadi 53\% dan memberi saran menjadi 63\%. Demikian pula dengan kemampuan aktivitas mental mengalami kenaikan yang meliputi kemampuan untuk menggapi 71\%, kemampuan menjawab pertanyaan 69\%, mengambil keputusan menjadi $73 \%$, dan kemampuan untuk mengingat menjadi 68\%. Dengan adanya absen voice maka peserta didik terpaksa harus hadir untuk memberikan suaranya, menyebutkan nama, kelas dan nomor absen dan mengatakan "saya hadir Bu". Hal ini membuat persentase kehadiran menjadi $78 \%$ yang artinya peserta didik hadir semua. Hal ini jelas stimulus mengubah perilaku yang awalnya peserta didik hanya menitip absen dengan mengetik atau mencentang dalam WAG, terpaksa mereka tetap memegang HP atau laptop. Sehingga pembelajaran benar-benar efektif karena semua anak terlibat dalam pembelajaran walaupun peserta didik tidak dapat melihat guru dan teman-temannya, namun dengan voice atau menulis di WAG menunjukkan bahwa peserta didik hadir atau ada. Begitu aktivitas emosi lainnya mengalami kenaikkan yang luar biasa yaitu peserta didik berani untuk menyatakan pendapat atau bertanya karena motivasi hadiah dan peserta didik membuktikan dirinya hadir dalam pembelajaran. Artinya eksistensi peserta didik diakui keberadaannya dalam mengikuti pembelajaran. Ketika pembelajaran berjalan dengan efektif dan transfer control stimulus berjalan sukses maka akan memengaruhi hasil belajar, karena setiap peserta didik merespon ketika guru memberi tugas, diawali dengan menerima file materi berupa PowerPoint yang harus dibaca, dirangkum, terakhir guru menjelaskan dan peserta didik merespon, sehingga peserta didik akan menyimpan ilmu yang telah dipelajari. Setelah dilakukan evaluasi, peserta didik mendapat nilai yang sangat memuaskan yaitu mengalami kenaikan dari $65,8 \%$ menjadi $73 \%$. Terakhir dengan stimulus yang lebih lengkap pencapaian menjadi $81 \%$, dengan ketuntasan $89 \%$ dan peserta didik yang belum tuntas $11 \%$.

Refleksi pada siklus II memperlihatkan hasil peningkatan yang signifikan. Hal ini bisa dilihat dari semakin bertambahnya aktivitas peserta didik dalam pembelajaran, berpendapat, bertanya, menanggapi, menjawab pertanyaan, mengambil keputusan, mengingat, dan kehadiran yang sempurna, serta mereka berani dan bersemangat dalam pembelajaran walaupun mereka tidak dapat melihat gurunya. Namun kehadiran mereka terdeteksi dengan baik, sehingga meningkatkan motivasi bagi mereka. Dari hasil belajar yang dicapai dalam siklus II dapat disimpulkan bahwa pembelajaran dengan memberi stimulus secara tepat atau mengubah perilaku melalui WAG bisa dikatakan berhasil, untuk itu tindakan pada siklus II ini dapat dihentikan. Hal ini menunjukkan bahwa pembelajaran daring melalui media sosial WAG jika diberi stimulus dan transfer control stimulus yang tepat maka akan meningkatkan aktivitas peserta didik dalam pembelajaran. Secara tidak langsung berpengaruh juga terhadap hasil pembelajaran PPKn.

Tabel 2. Data Observasi

\begin{tabular}{llccc}
\hline \multirow{2}{*}{ No } & \multirow{2}{*}{ Aktivitas Siswa } & \multicolumn{3}{c}{ Nilai } \\
\cline { 3 - 5 } & & Pra & Siklus I & Siklus II \\
\hline \multirow{2}{*}{1} & Aktivitas Verbal & & & \\
2 & Berpendapat & 58 & 64 & 71 \\
3 & Mertanya & 52 & 53 & 64 \\
& Aktivitas Mental & 51 & 50 & 63 \\
1 & Menanggapi & & & \\
2 & Menjawab pertanyaan & 51 & 56 & 69 \\
3 & Mengambil keputusan & 50 & 69 & 73 \\
4 & Mengingat & 49 & 60 & 68 \\
& Aktivitas Emosi & & & \\
1 & Hadir & 67 & 74 & 78 \\
2 & Berani & 58 & 62 & 77 \\
3 & Bersemangat & 46 & 59 & 63 \\
\hline & Jumlah & 535 & 600 & 697 \\
\hline
\end{tabular}


Pembahasan hasil penelitian didasarkan atas hasil pengamatan yang dilanjutkan dengan refleksi pada setiap siklus. Dari refleksi pra siklus bisa disimpulkan bahwa masih banyak yang belum mengeluarkan pendapat, menanggapi juga belum antusias apalagi bersemangat. Bahkan kehadirannya hanya sekedar hadir, setelah menulis kehadiran, terbukti $85 \%$ peserta didik menghilang tidak mengikuti pembelajaran. Karena absensinya hanya menulis di WAG, setelah itu tidak terkontrol lagi, guru hanya memberi file materi sehingga tidak terlacak keberadaan peserta didik. Oleh sebab itu dibuatlah stimulus untuk melakukan transfer control stimulus yang dilakukan mulai pada siklus I. Dengan cara kehadiran peserta didik melalui voice mail dengan menyebutkan nama, kelas dan nomor absen. Sehingga setiap peserta didik harus standby di depan laptop atau komputer. Karena kehadirannya harus ada, guru harus tahu bahwa peserta didik berada di depan ponsel atau laptop untuk belajar. Sebelum pembelajaran dimulai, guru memberi opening (pembukaan) dalam belajar, berdoa, mengirim file materi atau video. Peserta didik diharapkan untuk menulis isi materi dari file tersebut sebelum guru menjelaskan materi pembelajaran. Ketika guru menjelaskan melalui voice mail, maka peserta didik akan ditanya kembali tentang apa yang telah guru sampaikan. Peserta didik diminta untuk merespon apa yang dijelaskan oleh guru dengan menyebut nama, kelas dan nomor absen. Namun dalam siklus I pengaruhnya tidak terlampau jauh, karena guru hanya memerintah tanpa perilaku yang menyenangkan. Sehingga direncanakan ulang pada saat siklus II, guru memberi hadiah siapa saja yang memberi respon, jawaban, tanggapan, dan pertanyaan. Yang awalnya merespon hanya menulis saja di WAG, maka diharapkan responnya meningkat dengan menggunakan voice mail. Sehingga peserta didik berlomba-lomba dalam hal menjawab pertanyaan, karena ada nilai yang akan didapatkan. Peserta didik bersemangat hadir di kelas tepat waktu, sehingga pembelajaran online tidak mengurangi kedisplinan peserta didik dalam belajar. Peserta didik juga melakukan tes pada SIMAK dengan tepat waktu. Karena dalam SIMAK, peserta didik mengerjakan tes ditentukan batas waktu dan hasilnya langsung terlihat. Begitu juga tiap siklus hasil belajar akan terpengaruh dengan stimulus yang diberikan. Berikut perbandingan hasil transfer control stimulus:

Tabel 3. Data Perolehan Hasil Analisis Tes Hasil Belajar Peserta Didik

\begin{tabular}{|c|c|c|c|c|c|c|c|c|c|c|}
\hline \multirow{3}{*}{ No } & \multirow{3}{*}{ No Soal } & \multicolumn{3}{|c|}{ Pra Siklus } & \multicolumn{3}{|c|}{ Siklus I } & \multicolumn{3}{|c|}{ Siklus II } \\
\hline & & \multirow{2}{*}{ Nilai } & \multicolumn{2}{|c|}{ Siswa Tuntas } & \multirow{2}{*}{ Nilai } & \multicolumn{2}{|c|}{ Siswa Tuntas } & \multirow{2}{*}{ Nilai } & \multicolumn{2}{|c|}{ Siswa Tuntas } \\
\hline & & & Ya & Tidak & & Ya & Tidak & & $\mathrm{Ya}$ & Tidak \\
\hline 1 & 1 & 100 & 21 & & 100 & 27 & & 100 & 35 & \\
\hline 2 & 2 & 79 & & & 82 & & & 87 & & \\
\hline 3 & 3 & 79 & & & 82 & & & 89 & & \\
\hline 4 & 4 & 51 & & & 66 & & & 80 & & \\
\hline 5 & 5 & 20 & & & 35 & & & 48 & & \\
\hline$\% R$ & ata-rata & 65,8 & 53 & 47 & 73 & 69 & 21 & 80,8 & 89 & 11 \\
\hline
\end{tabular}

Dari hasil penelitian bisa disimpulkan bahwa terjadi kenaikan hasil belajar yang signifikan. Didukung oleh teori Watson bahwa semua organisasi akan menyesuaikan diri dengan lingkungannya melalui respon dan respon tertentu biasanya disebabkan oleh peristiwa (stimulus tertentu) yang dapat menghasilkan pembelajar yang efektif dan efesien (Gredler 2011). Walaupun sangat sederhana hanya memberi stimulus melalui WAG berupa absen, menjelaskan, menanggapi, merespon melalui voice mail, dan terakhir adalah hadiah berupa nilai. Hasilnya peserta didik merespon guru pada setiap memberi stimulus. Hal ini berpegang pada hukum Thorndike yang menyebutkan tiga hukum belajar yaitu hukum latihan, hukum kesiapan, dan hukum efek (Gredler 2011). Hukum latihan adalah ketika guru menjelaskan maka peserta didik diharapkan merespon mengulang apa yang disampaikan guru. Hukum kesiapan ketika guru memberikan stimulus berupa membuka pembelajaran, mengirim video atau file materi, peserta didik diperintahkan untuk merangkum, peserta didik diberi waktu 30 menit dan mengirim voice kehadiran ke WAG. Hal ini lebih mempersiapkan peserta didik untuk menerima penjelasan sehingga peserta didik lebih siap untuk belajar. Sehingga ketika guru menjelaskan dan bertanya, maka peserta didik berlomba-lomba untuk menjawab dan merespon stimulus. Hal ini juga untuk mengetahui apakah peserta didik memahami materi yang diberikan. Terakhir low of effects ketika guru memberi motivasi berupa nilai bagi peserta didik yang merespon stimulus tersebut. Maka guru akan memberi hadiah berupa nilai 1 (satu). Disamping itu juga tetap berpegang pada teori Skinner maka dalam hal ini guru menguraikan IPK dan materi menjadi lebih sederhana. Dengan berpegang 
pada teori Skinner dan Thorndike, maka guru berusaha dalam pembelajaran mengubah tingkah laku peserta didik melalui stimulus yang sangat sederhana melalui WAG secara berangsur-angsur melalui siklus I dan siklus II sehingga menghasilkan perilaku sebagai penguat Hasilnya peserta didik dapat meningkatkan keaktifan dalam pembelajaran dan meningkatkan hasil pembelajaran PPKn.

Penelitian ini dapat dikatakan berhasil karena: 1) peserta didik mampu melampaui KKM sebesar $8 \%$; 2) telah berhasil mengaktifkan peran serta peserta didik dalam pembelajaran melalui aktivitas verbal, aktivitas mental dan aktivitas emosi.

\section{SIMPULAN DAN SARAN}

Berdasarkan analisis yang telah dilakukan, pelaksanaan PTK yang dilaksanakan di kelas 7.1 dengan media pembelajaran WAG disimpulkan sebagai berikut: 1) penerapan pembelajaran PPKn dengan media pembelajaran WAG dapat meningkatkan aktivitas peserta didik dalam pembelajaran daring yang diperlihatkan dengan peningkatan rata rata persentase perolehan skor tiap siklus; 2) dari pra siklus, diperoleh persentase aktivitas peserta didik $67 \%$, siklus 1 diperoleh persentasenya $77 \%$ dan siklus 2 diperoleh persentasenya 87\%; 3) hasil belajar peserta didik dalam pembelajaran PPKn yang diperoleh melalui media WAG interaktif mengalami peningkatan ketuntasan belajar peserta didik yaitu 63\%, 73\% dan 89\%; 4) ketuntasan belajar secara klasikal tercapai pada siklus II mencapai 89\%.

Diharapkan hasil penelitian PTKini dapat memberi wawasan kepada guru untuk dapat meningkatkan inovasi dalam pembelajaran daring. Sarana dalam pembelajaran daring yang paling terjangkau dengan peserta didik adalah WAG dan guru dapat memaksimalkan pemanfaatan WAG sebagai media pembelajaran sehingga menghasilkan pembelajaran yang maksimal. Dengan menggunakan media pembelajaran akan terjadi pembelajaran yang interaktif, peserta didik tidak harus melakukan Zoom meet namun WAG dapat memenuhi pembelajaran yang efektif jika guru pandai mengemasnya dengan baik. Guru harus mampu mengajar dengan baik walau ada keterbatasan kondisi peserta didik dan tetap berpegang pada teori-teori belajar.

\section{PUSTAKA ACUAN}

Arikunto, Suharsini. Prosedur Penelitian Suatu Pendekatan Praktik. Jakarta: Rineka Cipta, 2015.

Gredler, Margaret. E-Learning And Instruktion Teori dan Aplikasi. Jakarta: Kencana Prenada Media Group, 2011.

Musfiqon, HM. Pengembangan Media dan Sumber Pembelajaran. Jakarta: Prestasi Pustaka, 2012.

Nana, Sudjana. Teknologi Pengajaran. Bandung: Sinar Baru Algensindo, 2007.

Sadikin, A. H. Ali. "Pembelajaran Daring di Tengah Wabah Covid." BIODIK: Jurnal Ilmiah Pendidikan Biologi (https://doi.org/10.17509/t. v6i2.20887) 6(2) (2020): 214-224.

Saputra, Lukman Surya. Buku Guru Pendidikan Pancasila dan Kewarganegaraan. Jakarta: Kementerian Pendidikan dan Kebudayaan, 2017.

Seels, Barbara B. Teknologi Pembelajaran Definisi dan Kawasannya. Jakarta: Unit Penerbitan Universitas Negeri Jakarta, n.d.

Stephen, Kemmis, and Mc Taggart. The Action Research Panner. Victoria: Deakin University Press, 1998.

Wilson, John P. Human Resource Development. London: Kogan Page, 2005. 